(C) 1983. The Genetical Society of Great Britain

\title{
ON THE POLYMORPHISM OF CYANOGENESIS IN LOTUS CORNICULATUS L. IX. SELECTIVE HERBIVORY IN NATURAL POPULATIONS AT PORTHDAFARCH, ANGLESEY
}

\author{
S. G. COMPTON, S. G. BEESLEY AND DAVID A. JONES \\ Unit of Genetics, University of Hull, Hull HUG 7RX
}

Received 10.iii.83

\begin{abstract}
SUMMARY
The $L$. corniculatus populations at Porthdafarch are polymorphic for the characters of leaf cyanogenesis, petal cyanogenesis and keel petal colour. Plants with cyanogenic leaves and petals occur less frequently on the sea cliffs than inland and previous studies have obtained circumstantial evidence of a link between the cline in leaf cyanogenesis and the distribution of selectively grazing molluscs. Counts of leaf and petal damage have confirmed that plants on the cliffs are grazed less heavily than those growing inland and have demonstrated that individuals with acyanogenic leaves or petals are liable to be chewed more heavily than their cyanogenic neighbours. Most of the damage was attributable to feeding by molluscs and it is concluded that herbivorous insects have only a minor role in the maintenance of the clines.
\end{abstract}

\section{INTRODUCTION}

The population of Lotus corniculatus L. on the cliff along the S. W. facing coast of Porthdafarch, Holy Island, Anglesey contains a lower proportion of plants with cyanogenic leaves than two nearby populations less than 200 metres inland (Jones, 1962). Because this cline appeared to have been stable for several years and the two inland sites had essentially the same proportions of cyanogenic plants, in spite of being topographically very different, Ellis et al., (1977) sought those environmental factors common to the inland sites by which they differed from the cliff site. They determined that the distribution of molluscs known to graze the acyanogenic form preferentially (Jones, 1966, Crawford-Sidebotham, 1972), together with "exposure" to wind and salt spray from the sea, were the principal factors involved. As there was a clear relationship between the distribution of the molluscs and exposure, they then looked for pairs of sites (in which $L$. corniculatus was growing) to the N.W. and S.E. of Porthdafarch, one site being exposed and the other member of the pair not exposed. They found that molluscs were confined almost exclusively to the unexposed sites, even on the two occasions when these were closer to the sea than the exposed sites. The plants were then tested for leaf cyanogenesis and without exception the proportion of cyanogenic plants was higher in each mollusc occupied site. They concluded that acyanogenic $L$. corniculatus were at a disadvantage in some areas of Holy Island because they were liable to suffer from disproportionately high levels of mollusc grazing and that differential herbivory was responsible for the pattern of distribution of the leaf cyanogenic individuals in that study area. 
Most European populations of $L$. coniculatus are also polymorphic for the characters of petal cyanogenesis and the colour of the keel petals. Cyanogenesis in the leaves and petals appears to segregate independently, but in the only native population that has been examined in sufficient detail there was a significant excess of individuals sharing the same phenotype (Jones and Crawford, 1977). Using cultivated material, Buzzell and Wilsie (1963) and Bubar and Miri (1965) have detected a locus which is involved in the control of both leaf cyanogenesis and keel colour and which results in an excess of acyanogenic light keeled plants. No such excess has been detected in natural populations (Jones and Crawford, 1977; Ramnani, 1979).

L. corniculatus supports an extensive insect fauna (Compton, 1983), several species of which display a preference for feeding on acyanogenic leaves and flower petals (Compton et al., in preparation). Ellis et al. (1977) were unable to include an assessment of the importance of insects in their study of $L$. corniculatus at Porthdafarch and it is clearly important to determine whether insect herbivores could be influencing the frequency of cyanogenesis in these populations.

This report describes the results of scoring plants growing at Porthdafarch for all three phenotypes and also for petal and leaf damage. The objectives of this research were to answer four questions. Is $L$. corniculatus less heavily grazed on the cliff tops? Do acyanogenic plants suffer greater damage from herbivory than their cyanogenic neighbours? Are insect herbivores influencing the distribution of cyanogenic plants? And is the cline for leaf cyanogenesis paralleled by similar clines in the frequencies of petal cyanogenic and dark keeled individuals?

\section{MATERIALS, METHODS AND LOCALITIES}

The bay at Porthdafarch is situated on the S.W. coast of Holy Island, Anglesey (Grid Reference SH 234 799) and has been described and illustrated by Ellis et al. (1977). There are three clearly defined areas, termed the cliff, the hollow and the mound, with the cliff separated from the mound by a distance of approximately 150 metres. The vegetation on the cliff forms a short turf, while the hollow supports a taller sward and the mound a heathland vegetation. Over a 16 year period Ellis et al. reported mean leaf cyanogenic frequencies of 25.7 per cent on the cliff, 74.2 per cent in the hollow and 68.0 per cent on the mound.

The $L$. corniculatus population in the hollow is relatively small and was not included in the sampling programmes during the present study. In 1979 the plants on the cliff and mound were sampled at intervals of at least one metre by removing a flower umbel and its associated leafy stem. The areas sampled on the cliff and the mound were essentially the same as those previously sampled (Ellis et al., 1977). The sampling method used has been described earlier (Jones, 1977) although it should be emphasised that the sampling points were distributed throughout each area. Keel colour was scored as either light and dark and damage to the petals was scored on a presence or absence basis. The insects found inside the flowers were also recorded. All the leaflets collected were scored either as chewed or undamaged. 
Leaflets were scored because, as Harper (1980) has argued, the food supply of herbivores is usually better defined in terms of food plant units such as leaves or buds rather than as the number of plants that are present. This point is particularly relevant for $L$. corniculatus which clones readily thereby making it often difficult to distinguish between individual genets. In 1982 two further samples were collected, but on these occasions only 20 leaflets (four leaves) per stem were examined whereas the number of absent leaflets was also counted. Outside the flowering season only leafy stems were available. Leaves and petals were tested for cyanogenesis using the sodium picrate test described by Jones (1977) and were scored as either cyanogenic $(++)$ or acyanogenic $(-)$. The three acyanogenic phenotypes ( + - have cyanoglucoside, but no $\beta$-glucosidase; -+ have $\beta$-glucosidase but no cyanoglucoside; - - have neither) were not separated. $L$. corniculatus petals require a longer incubation period than the leaves and were scored after 48 hours, rather than 24.

\section{Results}

The frequencies of leaf cyanogenic, flower cyanogenic and dark keeled individuals in the samples taken at Porthdafarch are given in table 1. Leaf

\section{TABLE 1}

The frequencies of cyanogenic and keel colour phenotypes in two sites at Porthdafarch, Anglesey

A. Leaf Cyanogenesis

Date

11 June 1979

22 May 1982

3 September 1982

Means

\begin{tabular}{cccccc}
\multicolumn{4}{c}{ Cliff } & \multicolumn{3}{c}{ Mound } \\
++ & $N$ & $\%$ & ++ & $N$ & $\%$ \\
15 & 55 & $27 \cdot 3$ & 53 & 56 & $94 \cdot 6$ \\
28 & 92 & $30 \cdot 4$ & 49 & 65 & $75 \cdot 4$ \\
20 & 60 & $33 \cdot 3$ & 40 & 60 & $66 \cdot 6$ \\
& & $30 \cdot 4$ & & & $78 \cdot 4$
\end{tabular}

B. Flower Cyanogenesis

Date

11 June 1979

22 May 1982

Means

C. Keel Colour

Date

11 June 1979

22 May 1982

Means

++
27
31

$N^{\text {Cliff }}$
52
93

$\%$
$51 \cdot 9$
$33 \cdot 3$
$40 \cdot 0$

$++$

38

58

\section{Mound}

N $\%$

$39 \quad 97 \cdot 4$

$65 \quad 89.2$

$92 \cdot 3$

$++=$ number of cyanogenic plants, $N=$ sample size, $\%=$ frequency of cyanogenesis (tables $\mathrm{A}$ and $\mathrm{B}$ ) or dark keel colour (table C).

cyanogenic frequencies are generally higher than those obtained between 1959 and 1975 (Ellis et al., 1977), but the cliff has retained a lower proportion of cyanogenic individuals. Within each site there is considerable variation between the proportions of cyanogenic plants recorded on different sampling dates. While this may reflect variation in phenotype frequencies between different sections of the cliff and mound habitats, the spring samples 
included only plants in flower and hence differential flowering time could be responsible. These differences within the two habitats do not vilify the large and consistant differences in the proportions of leaf cyanogenic individuals between the cliff and the mound and it is this latter difference that is the subject of this report. Flower cyanogenic plants are also more numerous on the mound than the cliff while at both sites cyanogenesis is more common in the flowers than in the leaves. The distribution of the keel colour morphs does not follow that of the cyanogenic polymorphisms and there is no significant difference between the mound and the cliff for keel colour (in $1979 \chi_{(1)}^{2}=1.09$, in $1982 \chi_{(1)}^{2}=1.04, P>0.05$ ).

Table $2 \mathrm{a}$ shows that there is a clear excess of individuals either with both leaves and petals cyanogenic or with neither cyanogenic, whereas there

\section{TABLE 2}

The relationship between leaf and flower cyanogenesis and keel colour in plants scored for combinations of characters

A. Flower and Leaf Cyanogenesis

(1) Cliff

Date

11th June 1979

22 May 1982

(2) Mound

\section{Date}

11 June 1979

22 May 1982

$$
\text { Leaf }
$$

$$
\text { Leaf }
$$

B. Flower Cyanogenesis and Keel Colour (mound and cliff sites combined)

\begin{tabular}{|c|c|c|c|c|c|c|c|}
\hline \multirow[b]{2}{*}{ Date } & \multicolumn{7}{|c|}{ Flower } \\
\hline & Keel Colour & Dark & Light & Dark & Light & $\chi_{(1)}^{2}$ & $P$ \\
\hline $\begin{array}{l}\text { 11June } 1979 \\
22 \text { May } 1982\end{array}$ & & $\begin{array}{r}4 \\
17\end{array}$ & $\begin{array}{l}22 \\
72\end{array}$ & $\begin{array}{l}4 \\
8\end{array}$ & $\begin{array}{l}61 \\
61\end{array}$ & $\begin{array}{l}1.97 \\
1.64\end{array}$ & $\begin{array}{l}>0.05 \\
>0.05\end{array}$ \\
\hline
\end{tabular}
Flower

C. Leaf Cyanogenesis and Keel Colour (mound and cliff sites combined) Flower

11 June 1979
22 May 1982

\begin{tabular}{ccccccc} 
& \multicolumn{6}{c}{ Flower } \\
Keel Colour & Dark & Light & Dark & & & \\
& & & & & $\chi_{(1)}$ & $P$ \\
4 & 64 & 5 & 38 & 1.17 & $>0.05$ \\
15 & 62 & 10 & 70 & 1.43 & $>0.05$ \\
\hline
\end{tabular}

is no relationship between the keel colour phenotype and either of the cyanogenic polymorphisms (tables $2 \mathrm{~b}$ and $2 \mathrm{c}$ ). The degree of association between the leaf and flower cyanogenic phenotypes did not differ significantly between the cliff and mound $\left(\chi_{(1)}^{2}=0.99, P>0.05\right)$. It should be noted that it was not possible to score all specimens for all three polymorphic characters and consequently the sample sizes in table 2 are not consistent. 
The data in table $3 a$ show that leaflet damage was greater on the mound than on the cliff in early summer $\left(\chi_{(1)}^{2}=91.86, P<0.001\right)$ although no

TABLE 3

Comparisons between the levels of damage sustained by L. corniculatus plants growing on the mound and cliff at Porthdafarch

\begin{tabular}{|c|c|c|c|c|c|c|}
\hline \multicolumn{7}{|l|}{ A. Leaf Chewing } \\
\hline & & Cliff & & & Mound & \\
\hline \multicolumn{2}{|l|}{ Date } & Total & $\%$ & Chewed & Total & $\%$ \\
\hline 11 June 1979 & 205 & 4002 & $5 \cdot 1$ & 568 & 4552 & $12 \cdot 5$ \\
\hline 22 May 1982 & 276 & 1835 & 15.0 & 236 & 1275 & 18.5 \\
\hline 3 September 1982 & 154 & 1136 & $13 \cdot 6$ & 131 & 1152 & $11 \cdot 4$ \\
\hline \multicolumn{7}{|l|}{ B. Petal chewing } \\
\hline & & Cliff & & & Mound & \\
\hline Flower umbels & Chewed & Total & $\%$ & Chewed & Total & $\%$ \\
\hline Date & & & & & & \\
\hline 11 June 1979 & 27 & 56 & $48 \cdot 2$ & 36 & 56 & $64 \cdot 3$ \\
\hline 22 May 1982 & 35 & 93 & $37 \cdot 6$ & 32 & 65 & $49 \cdot 2$ \\
\hline \multicolumn{7}{|l|}{ C. Absent leaflets } \\
\hline Leaflets & Absent & $\begin{array}{c}\text { Cliff } \\
\text { Present }\end{array}$ & $\%$ Missing & Absent & $\begin{array}{l}\text { Mound } \\
\text { Present }\end{array}$ & $\%$ Missing \\
\hline $\begin{array}{c}\text { Date } \\
22 \text { May } 1982\end{array}$ & & & & & & \\
\hline $\begin{array}{l}22 \text { May } 1982 \\
3 \text { September } 1982\end{array}$ & $\begin{array}{l}25 \\
64\end{array}$ & $\begin{array}{l}1835 \\
1136\end{array}$ & $\begin{array}{l}1 \cdot 3 \\
5 \cdot 3\end{array}$ & $\begin{array}{l}25 \\
48\end{array}$ & $\begin{array}{l}1275 \\
1152\end{array}$ & $\begin{array}{l}1 \cdot 9 \\
4 \cdot 0\end{array}$ \\
\hline
\end{tabular}

significant difference was recorded in September $1982\left(\chi_{(1)}^{2}=2.5, P>0.05\right)$. This pattern of leaf damage broadly corresponds with the different mollusc densities recorded at Porthdafarch by Ellis et al, (1977), but it appears that damage levels may not be greater on the mound throughout the whole year. The levels of petal damage in the samples (table $3 \mathrm{~b}$ ) also indicate that herbivore activity is typically greater on the mound. More leaflets were absent in September than in May (table 3c), but the numbers that were missing did not differ significantly between sites on either occasion.

Comparisons of the damage levels sustained by cyanogenic and acyanogenic plants growing in the same areas show that on the cliff the leaflet damage was equally distributed between the two phenotypes (table 4a). This was not the case on the mound, however, where acyanogenic plants suffered a disproportionately high level of leaflet damage (table 4b) and were clearly at a disadvantage in terms of herbivore load.

In the September 1982 sample the extent of damage to each leaflet was also recorded. Analysis of these data on a per plant basis leads to conclusions similar to those based on the presence or absence of leaflet damage (table 5). When scores for absent leaflets are also included in the analysis the acyanogenic plants on the mound are again found to have sustained significantly greater leaf losses (table 6).

The two way analysis of the combined data reveals the complexity of the situation. In neither of the analyses in tables $5 \mathrm{c}$ and $6 \mathrm{c}$ are the main effects significant although there is a significant phenotype $\mathbf{x}$ location interaction in table $6 \mathrm{c}$. The mean damage score for cyanogenic plants on the cliff is not significantly larger than that for the acyanogenic plants (tables 
TABLE 4

The proportions of chewed leaves on cyanogenic and acyanogenic $\mathrm{L}$. corniculatus plants growing at Porthdafarch. Damage scores from 13 very weakly cyanogenic plants have not been included

A. Cliff

\begin{tabular}{|c|c|c|c|c|c|c|}
\hline & Phenotype & $\begin{array}{l}\text { Damaged } \\
\text { leaflets }\end{array}$ & $\begin{array}{l}\text { Undamaged } \\
\text { leaflets }\end{array}$ & $\begin{array}{c}\% \\
\text { Damaged }\end{array}$ & $\chi_{(1)}^{2}$ & $\mathbf{P}$ \\
\hline \multirow{2}{*}{$\begin{array}{l}\text { Date } \\
11 \text { June } 1979\end{array}$} & ++ & 61 & 1088 & & & \\
\hline & - & 143 & 2640 & $5 \cdot 1$ & 0.048 & $>0.05$ \\
\hline \multirow[t]{2}{*}{22 May 1982} & ++ & 55 & 340 & $13 \cdot 9$ & & \\
\hline & - & 161 & 1104 & $12 \cdot 7$ & 0.381 & $>0.05$ \\
\hline \multirow[t]{2}{*}{3 September 1982} & ++ & 45 & 304 & $12 \cdot 9$ & & \\
\hline & - & 104 & 663 & $13 \cdot 6$ & 0.092 & $>0.05$ \\
\hline \multirow[t]{3}{*}{ Totals } & ++ & 161 & 1732 & $8 \cdot 5$ & & \\
\hline & - & 408 & 4407 & $8 \cdot 5$ & $0 \cdot 002$ & $>0 \cdot 05$ \\
\hline & \multicolumn{4}{|c|}{ Heterogenity $\chi_{(2)}^{2}=0.519 P>0.05$} & & \\
\hline \multicolumn{7}{|l|}{ B. Mound } \\
\hline \multirow[t]{2}{*}{$\begin{array}{c}\text { Date } \\
11 \text { June } 1979\end{array}$} & $\begin{array}{c}\text { Phenotype } \\
++\end{array}$ & $\begin{array}{c}\text { Damaged } \\
\text { leaflets } \\
465\end{array}$ & $\begin{array}{l}\text { Undamaged } \\
\text { leaflets } \\
3381\end{array}$ & $\begin{array}{c}\% \\
\text { damaged } \\
12 \cdot 1\end{array}$ & $x_{(1)}^{2}$ & $\mathbf{P}$ \\
\hline & - & 103 & 303 & $25 \cdot 4$ & 55.948 & $<0.001$ \\
\hline \multirow[t]{2}{*}{22 May 1982} & + & 163 & 763 & $17 \cdot 6$ & & \\
\hline & - & 63 & 246 & $20 \cdot 4$ & $1 \cdot 203$ & $>0.05$ \\
\hline \multirow[t]{2}{*}{3 September 1982} & ++ & 76 & 754 & $9 \cdot 2$ & & \\
\hline & - & 54 & 228 & $19 \cdot 1$ & $20 \cdot 357$ & $<0.001$ \\
\hline \multirow[t]{3}{*}{ Totals } & ++ & 704 & 4898 & $12 \cdot 6$ & & \\
\hline & - & 220 & 782 & $22 \cdot 0$ & $62 \cdot 266$ & $<0.001$ \\
\hline & \multicolumn{4}{|c|}{ Heterogeneity $\chi_{(2)}^{2}=15.242, P<0.001$} & & \\
\hline
\end{tabular}

\section{TABLE 5}

Aanlysis of variance of leaflet damage at Porthdafarch, September 1982. Twenty leaflets from each plant were examined, with leaflets that had less than one quarter of their area removed given a damage score of 0.25 and those with greater damage a score of 0.5

A. Between phenotype comparisons on the cliff

Mean damage scores, $(++)$ leaflets $0 \cdot 91,(-)$ leaflets 0.88

Between phenotypes

$\begin{array}{rll}\text { d.f. } & \text { M.S. } & \text { P } \\ 1 & 0 \cdot 01 & - \\ \mathbf{5 7} & 0.81 & \\ \mathbf{5 8} & & \end{array}$

Total

58

B. Between phenotype comparisons on the mound

Mean damage scores, $(++)$ leaflets $0 \cdot 54,(-)$ leaflets $1 \cdot 08$

Between phenotypes

Within phenotypes

Total

C. Two way analysis of variance

Between phenotypes

Between locations

Phenotype $\times$ location

Within plants

Total

$\begin{array}{rlc}\text { d.f. } & \text { M.S. } & \text { P } \\ 1 & 3.27 & <0.01 \\ 56 & 0.42 & \\ 57 & & \\ & & \\ \text { d.f. } & \text { M.S. } & \text { P } \\ 1 & 2.33 & >0.05 \\ 1 & 1.27 & >0.05 \\ 1 & 0.95\} & \\ 113 & 0.62\} & \\ 116 & & \end{array}$


TABLE 6

Analysis of variance of leaflet damage and absent leaflets at Porthdafarch, September 1982. Twenty leaflets from each plant were examined, with absent leaflets scored as $1 \cdot 0$, leaflets with less than one quarter of their area removed scored as 0.25 and those with greater than one quarter of their area removed scored as 0.5

A. Between phenotype comparisons on the cliff Mean scores, $(++)$ leaflets $2 \cdot 54,(-)$ leaflets $1 \cdot 71$

Between phenotypes

Within phenotypes

d.f.

M.S.

$\begin{array}{rr}1 & 8 \cdot 94 \\ 57 & 2 \cdot 72\end{array}$

Total

58

$\underset{>0 \cdot 05}{\stackrel{P}{0}}$

B. Between phenotype comparisons on the mound

Mean scores, $(++)$ leaflets $1 \cdot 24,(-)$ leaflets $2 \cdot 28$

Between phenotypes

Within phenotypes

Total

d.f.

M.S.

$12 \cdot 14$

1.67

56

57

C. Two way analysis of variance

Between phenotypes

Between locations

Phenotype $\times$ location

Within plants

1

$\underset{<0.01}{\mathbf{P}}$

Total

$\begin{array}{rrc}\text { d.f. } & \text { M.S. } & \text { P } \\ 1 & 1 \cdot 50 & - \\ 1 & 6 \cdot 35 & - \\ 1 & 19 \cdot 59 & <0 \cdot 01 \\ 113 & 2 \cdot 20 & \\ 116 & & \end{array}$

$5 a, 6 a)$ but in the combined analysis it is sufficient to negate the significantly greater damage to acyanogenic plants on the mound. Clearly we need to know whether the excess damage to cyanogenic plants on the cliff is the result of herbivory or of non-biotic agents.

The numbers of missing leaflets on the plants growing on the mound and cliff showed different seasonal patterns. On the mound the acyanogenic plants had more missing leaflets in both early and late summer (table 7) and this was presumably related to the greater leaf damage that this phenotype was sustaining (table 4). In contrast, the acyanogenic plants on the cliff did not have a higher proportion of missing leaflets, and in late

TABLE 7

The numbers of absent leaflets on $\mathrm{L}$. corniculatus stems at Porthdafarch

\begin{tabular}{|c|c|c|c|c|c|c|}
\hline \multirow[b]{2}{*}{ Date } & \multirow[b]{2}{*}{ Phenotype } & \multicolumn{2}{|c|}{ Leaflets } & \multirow{2}{*}{$\begin{array}{c}\% \\
\text { absent }\end{array}$} & \multirow[b]{2}{*}{$\chi_{(1)}^{2}$} & \multirow[b]{2}{*}{$\mathbf{P}$} \\
\hline & & Absent & Present & & & \\
\hline \multicolumn{7}{|l|}{ Cliff } \\
\hline \multirow[t]{2}{*}{22 May 1982} & ++ & 5 & 395 & $1 \cdot 25$ & & \\
\hline & - & 15 & 1265 & $1 \cdot 2$ & 0.02 & $>0.05$ \\
\hline \multirow[t]{2}{*}{3 September 1982} & ++ & 31 & 349 & $8 \cdot 2$ & & \\
\hline & - & 33 & 767 & $4 \cdot 1$ & $8 \cdot 17$ & $<0.01$ \\
\hline \multicolumn{7}{|l|}{ Mound } \\
\hline \multirow{2}{*}{22 May 1982} & ++ & 14 & 926 & $1 \cdot 4$ & & \\
\hline & - & 11 & 309 & $3 \cdot 4$ & $4 \cdot 66$ & $<0.05$ \\
\hline \multirow[t]{2}{*}{3 September 1982} & ++ & 30 & 830 & $3 \cdot 5$ & & \\
\hline & - & 18 & 282 & 6.0 & $3 \cdot 54$ & $>0.05$ \\
\hline
\end{tabular}


summer they had significantly fewer losses than the cyanogenic plants growing there (table 7).

On the cliff the plants with acyanogenic petals suffered greater petal damage in both 1979 and 1982 (table 8) and, after combining the damage

TABLE 8

Damage to L. corniculatus petals at Porthdafarch in relation to petal cyanogenic phenotype

\begin{tabular}{|c|c|c|c|c|c|c|}
\hline Date & Phenotype & $\begin{array}{c}\text { Damaged } \\
\text { umbels }\end{array}$ & $\begin{array}{c}\text { Undamaged } \\
\text { umbels }\end{array}$ & $\begin{array}{c}\% \\
\text { damaged }\end{array}$ & $x_{(1)}^{2}$ & $\mathbf{P}$ \\
\hline \multicolumn{7}{|l|}{ Cliff } \\
\hline \multirow[t]{2}{*}{11 June 1979} & ++ & 9 & 18 & $33 \cdot 3$ & & \\
\hline & - & 15 & 10 & $60 \cdot 0$ & $3 \cdot 71$ & $>0.05$ \\
\hline \multirow[t]{2}{*}{22 May 1982} & ++ & 9 & 22 & $29 \cdot 0$ & & \\
\hline & - & 27 & 35 & $43 \cdot 5$ & $1 \cdot 84$ & $>0.05$ \\
\hline \multirow[t]{2}{*}{ Totals } & ++ & 18 & 40 & $31 \cdot 0$ & & \\
\hline & - & 42 & 45 & $48 \cdot 3$ & $4 \cdot 26$ & $<0.05$ \\
\hline \multicolumn{7}{|c|}{ Heterogeneity $\chi_{(1)}^{2}=1 \cdot 29, P>0.05$} \\
\hline \multicolumn{7}{|l|}{ Mound } \\
\hline \multirow{2}{*}{22 May 1982} & $+t$ & 28 & 30 & $48 \cdot 3$ & & \\
\hline & & 4 & 3 & $57 \cdot 1$ & $0 \cdot 20$ & $>0.05$ \\
\hline
\end{tabular}

scores from the two samples, it can be concluded that the difference in damage levels was significant. In 1979 only one acyanogenic flower umbel was collected on the mound and so no between-phenotype comparisons of the damage levels can be made. Acyanogenic flowers were also infrequent in the mound samples of 1982 and this may account for the failure to detect significant differences in the damage sustained by the different phenotypes (table 8). Flowers with dark keels were in a minority at both sites and after combining scores from the cliff and mound there is no evidence that damage was associated with keel colour phenotype (table 9).

TABLE 9

Damage to L. corniculatus flowers at Porthdafarch in relation to keel petal colour. Mound and Cliff sites combined

\begin{tabular}{|c|c|c|c|c|c|c|}
\hline $\begin{array}{c}\text { Date } \\
\text { 11 June } 1979\end{array}$ & $\begin{array}{c}\text { Phenotype } \\
\text { Dark }\end{array}$ & $\begin{array}{c}\text { Damaged } \\
\text { umbels } \\
6\end{array}$ & $\begin{array}{c}\text { Undamaged } \\
\text { umbels }\end{array}$ & $\begin{array}{c}\% \\
\text { damaged }\end{array}$ & $x_{(1)}^{2}$ & $\mathbf{P}$ \\
\hline & Light & 60 & 43 & $42 \cdot 0$ & 0.24 & $>0.05$ \\
\hline \multirow[t]{2}{*}{22 May 1982} & Dark & 11 & 14 & 44.0 & & \\
\hline & Light & 57 & 76 & 42.9 & 0.01 & $>0.05$ \\
\hline
\end{tabular}

Hand searches and sweep-net sampling of $L$. corniculatus at Porthdafarch failed to find any leaf-chewing insects on the plants growing on the cliff. Leaf chewing insects were also uncommon inland and the lepidopteran Coleophora discordella Zell. was the only species detected. In 1979 a survey of the flower feeding insects was carried out. The most abundant inhabitants were found to be larvae of the beetle Hypera plantaginis (Degeer) and the eggs and larvae of a second beetle, Apion loti (Kirby). Both species were considerably more numerous on the mound, with $A$. loti being virtually 
TABLE 10

Insects present inside L. corniculatus flowers collected at Porthdafarch on 11 June 1979

\begin{tabular}{|c|c|c|c|c|c|c|}
\hline & & Cliff & & & Mound & \\
\hline $\begin{array}{l}\text { Species } \\
\text { Apion loti }\end{array}$ & $\begin{array}{c}\text { Flowers } \\
\text { examined } \\
167\end{array}$ & $\begin{array}{c}\text { No. of } \\
\text { insects } \\
1\end{array}$ & $\begin{array}{c}\text { Density } \\
\text { per flower } \\
0.006\end{array}$ & $\begin{array}{c}\text { Flowers } \\
\text { examined } \\
169\end{array}$ & $\begin{array}{c}\text { No. of } \\
\text { insects } \\
29\end{array}$ & $\begin{array}{c}\text { Density } \\
\text { per flower } \\
0.17\end{array}$ \\
\hline $\begin{array}{l}\text { Hypera } \\
\quad \text { plantaginis }\end{array}$ & 167 & 15 & 0.09 & 169 & 72 & 0.43 \\
\hline
\end{tabular}

absent from the flowers growing on the cliff (table 10). A. loti larvae develop inside the immature seed pods of $L$. corniculatus and do not damage the petals. $H$. plantaginis larvae feed on both petals and immature seed pods and were responsible for much of the recorded petal damge. $H$. plantaginis larvae were not present in greater numbers on acyanogenic flowers, however, (table 11) and it is therefore unlikely that this species was responsible for the differential petal damge observed on the cliff (table 7).

TABLE 11

The distribution of Hypera plantaginis larvae in relation to flower cyanogenic phenotype. Porthdafarch 11 June 1979, cliff site only

\begin{tabular}{lccc}
\hline & & H. plantaginis & L. corniculatus \\
larvae & flowers \\
Flower phenotype & ++ & 7 & 79 \\
& - & 6 & 62 \\
& \multicolumn{3}{c}{$\chi_{(1)}^{2}=0.02, P>0.05$} \\
\hline
\end{tabular}

\section{Discussion}

Ellis et al. (1977) concluded that the cline in leaf cyanogenesis at Porthdafarch was probably the result of the cliff area supporting fewer selectively grazing molluscs than the mound. The results presented here have confirmed that the $L$. corniculatus population on the mound is generally more heavily grazed, and have shown that the acyanogenic plants growing there are likely to be at a selective disadvantage because they suffer more leaf damage than their cyanogenic neighbours. The leaves of acyanogenic plants were not more heavily grazed on the cliff, where it can be concluded that neither phenotype is at an advantage in terms of selective herbivory. Leaf feeding insects appear to be infrequent on both the cliff and mound and most of the leaf damage at Porthdafarch was attributable to feeding by molluscs. The difference in damage levels between the two areas is nonetheless smaller than might have been predicted from the considerably higher density of molluscs recorded previously on the mound (Ellis et al., 1977). This may reflect the increased relative palatability of the predominantly acyanogenic cliff population. As the most abundant of the mollusc species found at Porthdafarch are known to display selective feeding (Keymer and Ellis, 1978) and their distribution is correlated with the observed levels of leaf damage, there is now considerable evidence in support of the hypothesis that variation in mollusc density is influencing the frequency of the leaf cyanogenic phenotype in these populations. 
Damage to the flower petals was also greater on the mound, but between phenotype comparisons of petal damage are limited by a shortage of acyanogenic individuals at the site and no differential damage was detected. Comparisons between plants growing on the cliff did show that acyanogenic petals were being more heavily damaged and this confirms the defensive capability of cyanogenesis in both the leaves and flowers of $L$. corniculatus.

Flowers on the cliff contained relatively low densities of insects and the distribution of the major petal feeding species (Hypera plantaginis) appears to be independent of flower phenotype. The larvae of this species have a limited host range, and Lotus spp. are the usual host plants (Compton, 1983). As $H$. plantaginis is also known to contain the cyanide de-toxifying enzyme rhodanese (Parsons and Rothschild, 1964) it is perhaps not surprising that this specialist herbivore should be undeterred by cyanogenesis. Other candidates for the selective flower feeding observed at the cliff site include molluscs and grasshoppers. The snail Helicella itala (L.) is known to prefer to feed on flowers rather than leaves (Malan, 1973). This species, together with the slug Deroceras reticulatum (Muller), are abundant at Porthdafarch and in laboratory feeding choice experiments they eat significantly more of the acyanogenic petal morph (Compton et al. in preparation). Grasshoppers are also present at Porthdafarch (Ellis et al., 1977) and we have found that $L$. corniculatus flowers are much more palatable than leaves to at least three species, all of which display selective eating in the laboratory. Identification of the species that are responsible for the selective feeding at Porthdafarch will require more extensive on-site observations both of the feeding behaviour and of the distribution of each species.

A relationship between the distribution of molluscs and the frequency of plant characters associated with herbivore resistance has also been demonstrated by Cates (1975) and Dirzo and Harper (1982). The latter have adopted a similar approach to ours in their studies of the interaction between slugs and Trifolium repens L., a plant that is also polymorphic for leaf cyanogenesis. Working in a field that is maintained as permanent grassland they have shown that cyanogenic plants were over represented in those areas of the field where mollusc densities were high and that leaflets on acyanogenic plants were being more heavily chewed than those on cyanogenic plants. Cates investigated the relationship between the slug Agriolimax columbianus (Gould) and Asarum caudatum Lindl., a plant which in North America is polymorphic for an unidentified chemical defence which makes the plant unacceptable to the slug. He found that in those parts of the plant range where slugs were abundant it was the less palatable form of $A$. caudatum which was the dominant morph, whereas elsewhere it was replaced by the palatable form which had a higher growth rate and greater seed production.

The metabolic costs of cyanogenesis are likely to be low, particularly for legumes (McKey, 1979) and there is no evidence that cyanogenic individuals of $L$. corniculatus are at any disadvantage in terms of reproductive output or vegetative growth (Jones, 1963; Keymer and Ellis, 1978). Keymer and Ellis did find that cyanogenic plants from Porthdafarch were less salt tolerant than acyanogenic plants, however, and this may explain the success of the latter on the cliff. In September 1982 the cyanogenic $L$. corniculatus growing on the cliff site had significantly more missing leaves 
than the acyanogenic plants. If this sample reflects a general difference in leaf fall then we may have detected the results of physiological stresses, such as salt spray, acting differentially on the two phenotypes.

The cyanogenic ability of $L$. corniculatus petals has been recognised for many years (Guérin, 1929) and the inheritance of this character has been studied by Rammani (1979). Less well understood is the relationship between cyanogenesis in the leaves and the petals. Jones and Crawford (1977) scored an $L$. corniculatus population in the West Midlands and found that although plants with all 16 possible combinations of phenotypes were present there was an excess of those individuals which shared the same phenotype in the leaves and flowers. The populations at Porthdafarch also display this association between phenotypes, but more formal genetic studies will be required before the basis of this relationship can be clarified. At Porthdafarch there is no association between the expression of keel colour and either leaf or flower cyanogenesis, and this agrees with studies in the West Midlands (Jones and Crawford, 1977) and Norway (Compton et al., in preparation) which have also failed to detect the excess of acyanogenic pale keeled plants that was predicted by the findings of Buzzell and Wilsie (1963).

In areas such as the cliff at Porthdafarch an association between the expression of cyanogenesis in the leaves and flowers would appear to be unfavourable because there is evidence that plants with cyanogenic petals may be at an advantage (due to reduced herbivory) while plants with cyanogenic leaves are at a disadvantage (due perhaps to being linked with reduced salt tolerance). If flower cyanogenesis is not also linked with salt tolerance then selection would be expected to favour plants with cyanogenic flowers and acyanogenic leaves and ultimately the independence of these two characters. There is no evidence that this separation has taken place, however, as individuals with different phenotypes for leaf and petal cyanogenesis were no more frequent on the cliff than the mound.

Flower damage is clearly linked with fecundity (both directly through ovule losses and indirectly via a reduction in pollination levels) and the protection evidently afforded by petal cyanogenesis can be assumed to have a significant bearing on reproductive output. Mature plants have a well documented ability to compensate for losses of leaf tissue and CrawfordSidebotham (1972) and Jones (1972) have argued that leaf cyanogenesis may be of most benefit to $L$. corniculatus during its seedling stage, when individuals are far more vulnerable. $L$. corniculatus is not an ideal subject for demographic studies (Keymer, 1978), but further investigation of the cline in cyanogenesis at Porthdafarch will clearly need to include an appraisal of the significance of cyanogenesis throughout the life history of the plant.

Acknowledgements. We would like to thank Ms V. Fairhurst for her technical assistance. The Science and Engineering Research Council provided financial support for S. G. Compton and S. G. Beesley. We are also grateful to the Natural Environment Research Council for supporting part of this work.

\section{REFERENCES}

BUBAR, J. S. AND MIR1. R. K. 1965. Inheritance of self-incompatibility and brown keel tip in Lotus corniculatus L. Nature, 205, 1035-1036. 
BUZZELL, R. I. AND WILSIE, C. P. 1963. Genetic investigation of brown keel tip colour in Lotus corniculatus L. Crop Science, 3, 128-130.

CATES, R. G. 1975. The interface between slugs and wild ginger: some evolutionary aspects. Ecology, 56, 391-400.

COMPTON, S. G. 1983. Studies of insects associated with Lotus corniculatus L. Ph. D. Thesis, University of Hull.

CRAWFORD-SIDEBOTHAM, T. J. 1972. The role of slugs and snails in the maintenance of the cyanogenesis polymorphisms of Lotus corniculatus and Trifolium repens. Heredity, 28 , 405-411.

DIRZO, R. AND HARPER, J. L. 1982. Experimental studies on slug-plant interactions III. Differences in the acceptability of individual plants of Trifolium repens to slugs and snails. J. Ecol., 70, 101-117.

ELLIS, W. M., KEYMER, R. J. AND JONES, D. A. 1977. On the polymorphism of cyanogenesis in Lotus corniculatus L. VIII. Ecological studies in Anglesey. Heredity, 39, 45-65.

GUÉRIN, P. 1929. La teneur en acide cyanhydrique des Lotus. C.r. Lebd. Séanc. Acad. Sci., Paris, 187, 1011-1013.

HARPER, J. L. 1980. Plant demography and ecological theory. Oikos, 35, 244-253.

JONES, D. A. 1962. Selective eating of the acyanogenic form of the plant Lotus corniculatus L. by various animals. Nature, 193, 1109-1110.

JONES, D. A. 1963. Polymorphisms and Antibodies in lower organisms. D. Phil. Thesis, University of Oxford.

JONES, D. A. 1966. On the polymorphism of cyanogenesis in Lotus corniculatus. Selection by animals. Can. J. Genet. Cytol., 8, 556-567.

JONES, D. A. 1972. Cyanogenic Glycosides and their Function. In Harborne J. B. (ed.) Phytochemical Ecology, Academic Press, London, pp 103-124.

JONES, D. A. 1977. On the polymorphism of cyanogenesis in Lotus corniculatus L. VII. The distribution of the cyanogenic form in Western Europe. Heredity, 39, 27-44.

JONES, D. A. AND CRAWFORD, T. J. 1977. Variation in the colour of the keel petals in Lotus corniculatus L. I. The polymorphism in Western Europe. Heredity, 39, 313-325.

KEYMER, R. J. 1978. Genecological studies of cyanogenesis in Lotus corniculatus (L.). Ph.D. Thesis, University of Hull.

KEYMER, R. J. AND ELLIS, W. M. 1978. Experimental studies on plants of Lotus corniculatus L. from Anglesey polymorphic for cyanogenesis. Heredity, 40, 189-206.

MALAN, M. A. 1973. Preliminary studies of the ecology of the heath snail Helicella itala (L.). M.Sc. Thesis, University College of North Wales, Bangor.

MCKEY, D. 1979. The distribution of secondary compounds within plants. In Rosenthal, G. A. and Janzen, D. H. (eds.). Herbivores: their interaction with secondary plant metabolites. Academic Press, London pp 55-133.

PARSONS, J. AND ROTHSCHILD, M. 1964. Rhodanese in the larvae and pupae of the common blue butterfly (Polyommatus icarus Rott., Lepidoptera). Ent. Gaz., 15, 58-59.

RAMNANI, A. D. 1979. Studies on cyanogenesis and the colour of the keel petals of Lotus corniculatus (L.). Ph.D. Thesis, University of Hull. 